\title{
Immune system modeling and analysis
}

\section{Ramit Mehr* \\ Computational Immunology Lab, The Mina and Everard Goodman Faculty of Life Sciences, Bar-Ilan University, Ramat-Gan, Israel \\ ${ }^{*}$ Correspondence: ramit.mehr@biu.ac.il}

Edited and reviewed by:

Thomas L. Rothstein, The Feinstein Institute for Medical Research, USA

Keywords: immune system, mathematical modeling, lymphocytes, repertoire, immunomics

Immunologists currently face daunting challenges, as a result of the rapid development of new methods for immunological data collection, from high-throughput phenotyping to deep sequencing (1). These and similar methods keep generating humongous amounts of immunological data, which in turn challenge the theoretical immunology community to develop methods for data organization and analysis and mathematical and computational modeling. These challenges and methods were discussed in recent workshops, for example the Lymphocyte Repertoire Workshop (Institute of Advanced Studies of the Hebrew University, Jerusalem, early 2012, organized by myself), and the International Seminar on Multi-Scale Physics of Lymphocyte Development (Max Planck Institute for the Physics of Complex Systems, Dresden, Summer 2012, organized by M. OrGuil et al.).

At about the same time, the organizers mentioned above were approached by the Frontiers editorial staff with the idea for a "Frontiers in Immunology" research topic, which was to provide a comprehensive, online, open access snapshot of the current state of the art on immune system modeling and analysis. The research topic was launched, edited, and finalized with the kind help of co-editors Rob de Boer, Miles Davenport, Carmen Molina-Paris, Michal Or-Guil, and Veronika Zarnitsyna. It has been a success, with 35 papers accepted for publication, which attests to the timeliness of the topic.

The papers included in this Research Topic reflect many of the issues that theoretical immunologists are struggling with. Some of the papers address old questions - such as the targeting of somatic hypermutation (2) and the resulting diversity of B cell repertoires $(3,4)$, how clonal selection operates in germinal centers (5-8); or how the $\mathrm{T}$ cell compartment develops (9-11) and changes with aging (12). However, these papers offer new viewpoints, which emerged thanks to the immunological "data revolution", in particular next-generation sequencing of lymphocyte repertoires. Others address new methods of extracting (13-15) and analyzing (16-18) comprehensive T and B cell phenotype and repertoire data, and delineate some of the first insights gleaned from sequencing studies regarding how these repertoires emerge, evolve, and function (19-25). Natural killer cells (26), myeloid cells (27), and structural immunology (28-31) are also represented.

My thanks go to the above-mentioned co-editors, to the responsive and efficient Frontiers editorial staff, to all the authors who contributed papers, and to the reviewers whose work has made publication of all these papers possible.

\section{REFERENCES}

1. Mehr R, Sternberg-Simon M, Michaeli M, Pickman Y. Models and methods for analysis of lymphocyte repertoire generation, development, selection and evolution. Immunol Lett (2012) 148:11. doi:10.1016/j.imlet.2012.08. 002

2. Yaari G, Vander Heiden JA, Uduman M, Gadala-Maria D, Gupta N, Stern JN, et al. Models of somatic hypermutation targeting and substitution based on synonymous mutations from high-throughput immunoglobulin sequencing data. Front Immunol (2013) 4:358. doi:10.3389/fimmu.2013.00358

3. Jackson KJ, Kidd MJ, Wang Y, Collins AM. The shape of the lymphocyte receptor repertoire: lessons from the B cell receptor. Front Immunol (2013) 4:263. doi:10.3389/fimmu.2013.00263

4. Michaeli M, Tabibian-Keissar H, Schiby G, Shahaf G, Pickman Y, Hazanov $\mathrm{L}$, et al. Immunoglobulin gene repertoire diversification and selection in the stomach - from gastritis to gastric lymphomas. Front Immunol (2014) 5:264. doi:10.3389/fimmu.2014.00264

5. Schwartz GW, Hershberg U. Germline amino acid diversity in B cell receptors is a good predictor of somatic selection pressures. Front Immunol (2013) 4:357. doi:10.3389/fimmu.2013.00357

6. Liberman G, Benichou J, Tsaban L, Glanville J, Louzoun Y. Multi step selection in Ig $\mathrm{H}$ chains is initially focused on CDR3 and then on other CDR regions. Front Immunol (2013) 4:274. doi:10.3389/fimmu.2013.00274

7. Kepler TB, Munshaw S, Wiehe K, Zhang R, Yu JS, Woods CW, et al. Reconstructing a B-cell clonal lineage. II. Mutation, selection, and affinity maturation. Front Immunol (2014) 5:170. doi:10.3389/fimmu.2014.00170

8. Or-Guil M, Faro J. A major hindrance in antibody affinity maturation investigation: we never succeeded in falsifying the hypothesis of single-step selection. Front Immunol (2014) 5:237. doi:10.3389/fimmu.2014.00237

9. Yates AJ. Theories and quantification of thymic selection. Front Immunol (2014) 5:13. doi:10.3389/fimmu.2014.00013

10. Reynolds J, Coles M, Lythe G, Molina-París C. Mathematical model of naive T cell division and survival IL-7 thresholds. Front Immunol (2013) 4:434. doi:10.3389/fimmu.2013.00434

11. Hapuarachchi T, Lewis J, Callard RE. A mechanistic model for naive CD4 T cell homeostasis in healthy adults and children. Front Immunol (2013) 4:366. doi:10.3389/fimmu.2013.00366

12. Shifrut E, Baruch K, Gal H, Ndifon W, Deczkowska A, Schwartz M, et al. CD4+ $\mathrm{T}$ cell-receptor repertoire diversity is compromised in the spleen but not in the bone marrow of aged mice due to private and sporadic clonal expansions. Front Immunol (2013) 4:379. doi:10.3389/fimmu.2013.00379

13. Fiala GJ, Kaschek D, Blumenthal B, Reth M, Timmer J, Schamel WW. Preclustering of the $\mathrm{B}$ cell antigen receptor demonstrated by mathematically extended electron microscopy. Front Immunol (2013) 4:427. doi:10.3389/ fimmu.2013.00427

14. Mamedov IZ, Britanova OV, Zvyagin IV, Turchaninova MA, Bolotin DA, Putintseva EV, et al. Preparing unbiased T-cell receptor and antibody cDNA libraries for the deep next generation sequencing profiling. Front Immunol (2013) 4:456. doi:10.3389/fimmu.2013.00456

15. Chylek LA, Holowka DA, Baird BA, Hlavacek WS. An interaction library for the FceRI signaling network. Front Immunol (2014) 5:172. doi:10.3389/fimmu. 2014.00172

16. Bocharov G, Luzyanina T, Cupovic J, Ludewig B. Asymmetry of cell division in CFSE-based lymphocyte proliferation analysis. Front Immunol (2013) 4:264. doi:10.3389/fimmu.2013.00264 
17. Thomas-Vaslin V, Six A, Ganascia JG, Bersini H. Dynamical and mechanistic reconstructive approaches of $\mathrm{T}$ lymphocyte dynamics: using visual modeling languages to bridge the gap between immunologists, theoreticians, and programmers. Front Immunol (2013) 4:300. doi:10.3389/fimmu.2013. 00300

18. Zarnitsyna VI, Evavold BD, Schoettle LN, Blattman JN, Antia R. Estimating the diversity, completeness, and cross-reactivity of the T cell repertoire. Front Immunol (2013) 4:485. doi:10.3389/fimmu.2013.00485

19. Collins AM, Jackson KJ. A temporal model of human IgE and IgG antibody function. Front Immunol (2013) 4:235. doi:10.3389/fimmu.2013. 00235

20. Gong C, Linderman JJ, Kirschner D. Harnessing the heterogeneity of T cell differentiation fate to fine-tune generation of effector and memory T cells. Front Immunol (2014) 5:57. doi:10.3389/fimmu.2014.00057

21. Six A, Mariotti-Ferrandiz ME, Chaara W, Magadan S, Pham HP, Lefranc MP, et al. The past, present, and future of immune repertoire biology the rise of next-generation repertoire analysis. Front Immunol (2013) 4:413. doi:10.3389/fimmu.2013.00413

22. León K, García-Martínez K, Carmenate T. Mathematical models of the impact of IL2 modulation therapies on T cell dynamics. Front Immunol (2013) 4:439. doi:10.3389/fimmu.2013.00439

23. Caridade M, Graca L, Ribeiro RM. Mechanisms underlying CD4+ Treg immune regulation in the adult: from experiments to models. Front Immunol (2013) 4:378. doi:10.3389/fimmu.2013.00378

24. Gerdes S, Newrzela S, Glauche I, von Laer D, Hansmann ML, Roeder I. Mathematical modeling of oncogenesis control in mature T-cell populations. Front Immunol (2013) 4:380. doi:10.3389/fimmu.2013.00380

25. Kessinger TA, Perelson AS, Neher RA. Inferring HIV escape rates from multilocus genotype data. Front Immunol (2013) 4:252. doi:10.3389/fimmu.2013. 00252

26. Carrillo-Bustamante P, Kesmir C, de Boer RJ. Quantifying the protection of activating and inhibiting NK cell receptors during infection with a CMV-like virus. Front Immunol (2014) 5:20. doi:10.3389/fimmu.2014.00020
27. Alagha A, Zaikin A. Asymmetry in erythroid-myeloid differentiation switch and the role of timing in a binary cell-fate decision. Front Immunol (2013) 4:426. doi:10.3389/fimmu.2013.00426

28. Sela-Culang I, Kunik V, Ofran Y. The structural basis of antibody-antigen recognition. Front Immunol (2013) 4:302. doi:10.3389/fimmu.2013.00302

29. Sun J, Kudahl UJ, Simon C, Cao Z, Reinherz EL, Brusic V. Large-scale analysis of B-cell epitopes on influenza virus hemagglutinin - implications for crossreactivity of neutralizing antibodies. Front Immunol (2014) 5:38. doi:10.3389/ fimmu.2014.00038

30. Rao X, De Boer RJ, van Baarle D, Maiers M, Kesmir C. Complementarity of binding motifs is a general property of HLA-A and HLA-B molecules and does not seem to effect HLA haplotype composition. Front Immunol (2013) 4:374. doi:10.3389/fimmu.2013.00374

31. Castro M, van Santen HM, Férez M, Alarcón B, Lythe G, Molina-París C. Receptor pre-clustering and $\mathrm{T}$ cell responses: insights into molecular mechanisms. Front Immunol (2014) 5:132. doi:10.3389/fimmu.2014.00132

Conflict of Interest Statement: The author declares that the research was conducted in the absence of any commercial or financial relationships that could be construed as a potential conflict of interest.

Received: 02 September 2014; accepted: 03 December 2014; published online: 19 December 2014.

Citation: Mehr R (2014) Immune system modeling and analysis. Front. Immunol. 5:644. doi: 10.3389/fimmu.2014.00644

This article was submitted to B Cell Biology, a section of the journal Frontiers in Immunology.

Copyright (c) 2014 Mehr. This is an open-access article distributed under the terms of the Creative Commons Attribution License (CC BY). The use, distribution or reproduction in other forums is permitted, provided the original author(s) or licensor are credited and that the original publication in this journal is cited, in accordance with accepted academic practice. No use, distribution or reproduction is permitted which does not comply with these terms. 